\title{
レーザードップラー血流計を用いた口蓋粘膜の血流測定
}

\author{
山口由紀子, 菊池雅彦, 奥川博司, 渡辺 誠 \\ 東北大学歯学部高齢者歯科学講座 (主任：渡辺 誠 教授) \\ 〔受付：平成10年 1 月 16 日〕
}

\section{Measurement of blood flow in palatal mucosa using the laser Doppler flowmeter}

\author{
Yukiko Yamaguchi, Masahiko Kikuchi, Hiroshi Okugawa, Makoto Watanabe \\ Department of Geriatric Dentistry, Tohoku University School of Dentistry
}

(Director: Prof. Makoto Watanabe)

[Received: January 16, 1998.]

Key words: laser Doppler flowmeter, blood flow, palatal mucosa, mechanical load, reactive hyperemia

\begin{abstract}
The purpose of this study was to investigate the effects of mechanical load on blood flow in the palatal mucosa. In five healthy dentate subjects (mean age $26.4 \mathrm{yrs}$ ), the blood flow in palatal mucosa was measured using the laser Doppler flowmeter. A $400 \mathrm{gf}$ load was applied through a $4 \mathrm{~mm}$-diameter probe in the posterio-lateral aspect and the central rugae area of the palate for $40 \mathrm{~s}$. The blood flowmetry in the posterio-lateral site of the palate was also performed for loading intervals of 10,20 and $30 \mathrm{~s}$, and for the load intensity of 100,200 and 400 gf, respectively. The results obtained were as follows:

1. The effect of load on blood flow varied with the site of force application in the palate. A reactive hyperemia was almost always observed after the removal of load in the posterio-lateral region. However, no reaction or unclear reactive hyperemia was noted at the anterior site.

2 . There was a tendency that an increase in the loading interval extended the recovery period to the baseline. The reduction in blood flow during the load and its increase after the load removal tended to be constant regardless of the loading interval.
\end{abstract}

3. An increase in load intensity resulted in the reduction of blood flow during loading and the extension of recovery period. On the other hand, the degree of increase in blood flow after the load removal was not affected by the change of load intensity.

4. The relationships between the loading interval and the recovery period, between the load intensity and the recovery period, and between the load intensity and the reduction in blood flow during the load were considered to be useful parameters for evaluating the characteristics of the palatal mucosa.

抄録 本研究は, 口蓋粘膜への荷重負荷が血流量に及ほす影響を，レーザードップラー血流計を用いて検 索することを目的に行った．実験は 5 名の健常者（平均年齢26.4歳）を被験者とし，レーザードップラー 血流計を用いて，口蓋後側方部および口蓋正中部（口蓋ヒダ部）に直径 $4 \mathrm{~mm}$ のプローブを介して，荷重 量400gf，40秒間の加圧を行ったときの血流量を測定した。さらに，口蓋後側方部において，同じく荷重 量400gfで加圧時間を $10 ， 20 ， 30$ 秒と変化させた場合，および加圧時間40秒で荷重量を100，200，400gfと 
変化させた場合の血流量を測定した，その結果, 以下の結論を得た.

1. 加圧部位の相違による血流変化については, 口蓋後側方部の左右側粘膜では加圧終了直後に反応性の 充血がほとんどの場合で出現したが，口蓋正中部では反応性充血が出現しないか明確でない場合が多か った。

2. 加圧時間の相違による血流量変化については，加圧時間が増加した場合，加圧前の血流レべルに戻る までの回復時間は延長する傾向がみられた。これに対して，加圧時の血流減少量ならびに加圧後の血流 増加量は加圧時間に関係なく, ほほ一定となる傾向を示した。

3. 荷重量の相違による血流量変化については, 荷重量が増加した場合には, 回復時間は延長する傾向が みられた。 また, 加圧時の血流滅少量も荷重量増加に伴って増大する傾向を示した。一方, 加圧後の血 流増加量については，荷重量の変化によって一定の傾向は認められなかった.

4. 以上のことから, 加圧時間と回復時間, 荷重量と回復時間, および荷重量と加圧時血流隇少量との間 にはそれぞれ一定の関係が認められ，顎粘膜の性状や特性を評価する指標として有効であることが示唆 された.

\section{I. 緒 言}

有床義歯の装着は，歯の喪失により失われた顎口腔系 機能を回復することを目的としており，その目的を達成 するためには，床下支持組織を健康に保つことが必要で ある。しかしながら，義歯床下粘膜では，発赤・腫脹・ 圧痕や潰瘍の形成などの組織変化を生じることが少なく ない，このような変化の原因として，義歯床下粘膜面に 局所的に過大な咬合圧が作用していることが考えられ る。また，咬合圧作用時における患者固有の粘膜の反応， すなわち, 被圧による変位や血流量の変化などの因子も 関連していることが推察される。

これまで, 義歯床下粘膜の性状については, 粘膜の厚 径”や被圧変位性" などの形態的・物理的特性に関して 検討がなされているが，損傷を受けた組織の回復に直接 の影響を及ほすと思われる血流動態の検討は，必ずしも 十分とはいえない。

義歯に加わった咬合圧に対する組織反応は，まず微小 循環路周囲に起こることから, 床下粘膜の性状を検索す るための手段として, 義歯床下粘膜の血流動態の解析を 行うことが有効であると思われる，さらに，血流動態を 指標として個々の患者の床下粘膜の性状を評価・診断す ることが可能になれば，義歯の製作や予後の評価に応用 できるものと考えられる.

そこで本研究では，口蓋粘膜への荷重負荷による末梢 血液循環への影響を明らかにすることを目的とし，荷重 時の血流動態をレーザードップラー血流計を用いて検討 した。

\section{II. 研究方法}

\section{1．被験者}

被験者は，正常な歯列および咬合関係を有し，臨床的 に口蓋粘膜の異常を認めず，かつ全身的疾患のない25歳 から 29 歳の健常者 5 名（男 3 名，女 2 名，平均年䶔 26.4

歳）とした。

\section{2. 加圧装置}

手指によって粘膜に一定の荷重を加えるために，図 1 に示すような加圧装置を作製した，本装置はL 字型真ち

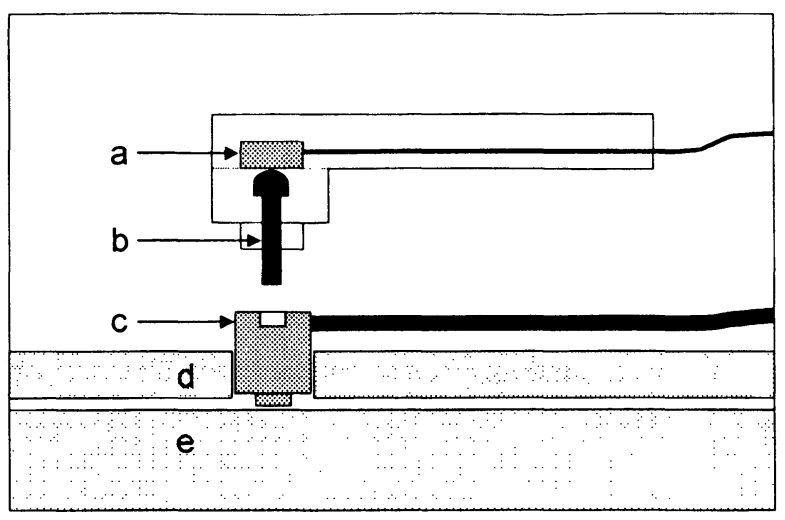

図 1 加圧装置および測定用プローブ模式図

$$
\begin{aligned}
& \mathrm{a} \text { : 圧カトランスデューサ b : 加圧子 } \\
& \mathrm{c} \text { : プローブ } \mathrm{d} \text { ：レジンステント } \\
& \mathrm{e} \text { ：口蓋粘膜 }
\end{aligned}
$$

Fig. 1 Schematic drawing of the loading equipment and the measuring probe of laser Doppler flowmeter

$a$ : Pressure transducer $b$ : Loading rod c: Probe d: Resin stent e: Palatal mucosa 


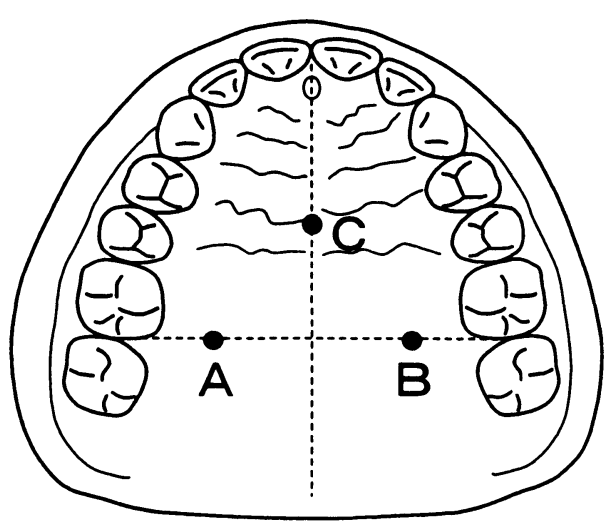

図 2 血流測定部位

Fig. 2 The measuring sites of blood flow

ゆう製ハウジングに，圧カトランスデューサ（PS-30KA, 共和電業社製) が設置されており, 軸方向に可動する加 圧子の上面中央部が圧カトランスデューサ中央部に接す ることにより，荷重量を測定することができる，圧方卜 ランスデューサからの信号はストレインアンプによって 增幅され, ボルトメーターに出力電圧を表示させた。

\section{3. 血流測定}

血流量の測定には，レーザードップラー血流計 PerifluxPF3 (Perimed社) を用いた。照射されるレーザ 一光は $2 \mathrm{~mW}$ の低出力He-Neレーザーで, 測定範囲はプ ローブ先端半径約 $1 \mathrm{~mm}$ の半球形部分である. ドップラ ーシフト周波数範囲は $12 \mathrm{kHz}$, 時定数は 0.2 秒とした.

図 1 に示すように, 粘膜の加圧は測定用プローブを介 して行うため, プローブ上面を加圧装置の安定が得られ るような凹型形態に改良し，プローブ先端の粘膜面に接 する部位は直径 $4 \mathrm{~mm}$ の平面とした。血流量の記録には, ペンレコーダ（SS-100, SECONIC社）を用いた．測定部 位は 3 力所とし, 両側第 1 大臼歯遠心の口蓋側歯肉縁と 口蓋正中線との中点（右側を $\mathrm{A}$ 点，左側を $\mathrm{B}$ 点），およ び小臼歯付近の口蓋正中部（C点）とした（図2）。ま た, 測定に際してプローブを粘膜に対して一定の位置に 保持するために, 被験者ごとに即時重合レジンを用いて 厚さ $2 \mathrm{~mm}$ のステントを作製した。 ステントは口蓋粘膜 に接触しないよう $0.5 \mathrm{~mm}$ のワックススペーサーを付与し て作製し，上顎全歯にわたる咬合面にその維持を求めた。 ステント内の測定部位には, プローブの直径よりもわず かに大きい径の保持孔を設け, 加圧時にステントとプロ 一ブの摩擦抵抗がなく，定位置での測定が行えるように した．なお，ステントの前歯相当部には，プローブと本
体をつなぐファイバーを固定するために，各保持孔に対 応したソケットを 3 カ所設置した。

血流測定は, 午後 2 時から 4 時の時間帯に行い, 血流 測定開始の約 30 分前に血流計の電源を入れて装置の安定 をはかった，測定に際しては, 被験者の体位による血流 量の変動を防止するために, 被験者をデンタルチェアー 上の仰臥位にて安静を保たせた。

\section{4. 測定部位における口蓋粘膜厚径の測定}

血流測定に先立ち, 測定部位の特徵を知るために粘膜 厚径の測定を刺入法により行った"．各々の測定部位に 表面麻酔後, 約 $0.1 \mathrm{ml}$ の $2 \%$ エピネフリン入キシロカイ ンで浸潤麻酔を行い，15分間経過してから測定を開始し た. 30G（ゲージ）の浸麻針にリーマー用のストッパー を付与し, 粘膜に刺入した後先端が抵抗を受けたところ でストッパーを粘膜面に接触させ,リーマーを静かに引 き抜いて，ストッパーと先端との距離を精度 $1 / 20 \mathrm{~mm} の$ ノギスで測定した，測定は一部位について 3 回行い, 平 均值を求めた。

\section{5. 測定条件}

1 ）加圧部位の相違による血流量の変化

図 2 に示す $\mathrm{A}, \mathrm{B}, \mathrm{C}$ の 3 点において, 加圧時間 40 秒, 荷重量400gfで加圧したときの血流量を測定した。

2 ）加圧時間の相違による血流量の変化

図 2 に示す $\mathrm{A}$ 点において, 荷重量 $400 \mathrm{gf}$ で, 加圧時間 を10，20，30秒と変化させた際の血流量を測定した.

3 ）荷重量の相違による血流量の変化

図 2 に示す $\mathrm{A}$ 点において, 加圧時間 40 秒で, 荷重量を $100,200,400 \mathrm{gf}$ 変化させた際の血流量を測定した。

いずれの場合も, 同一条件の試行を 3 回ずつ行い, 各 試行の間は最低 3 分間の安静状態を保った.

\section{6. 実験手順}

ステントを歯列に固定後, 保持孔に測定用プローブを 挿入して, 粘膜にわずかに接触させ, 安静状態の血流測 定を行った。粘膜加圧の際には, 加圧装置を手指で保持 し, プローブ上部に加圧子先端を接触させて荷重量をモ ニターしながら, 粘膜に対して可及的に垂直な方向に所 定の荷重を加え, 所定時間経過後, 加圧装置をプローブ 上面から静かに引き離した，血流量の記録は，加圧開始 前の安静時血流レベルを約 1 分間と, 加圧終了後に変動 した血流量が安静時血流レベルに近づき, 約 1 分間程度 持続して一定值を示すまでの区間を含むこととした．

\section{7. 分析項目}

図 3 に, 血流変化の原波形と分析項目を示す. 本研究 では, 血流量が加圧終了後からリバウンド様の変化, す なわち反応性の充血を経て加圧前のレベルに戻るまでの 


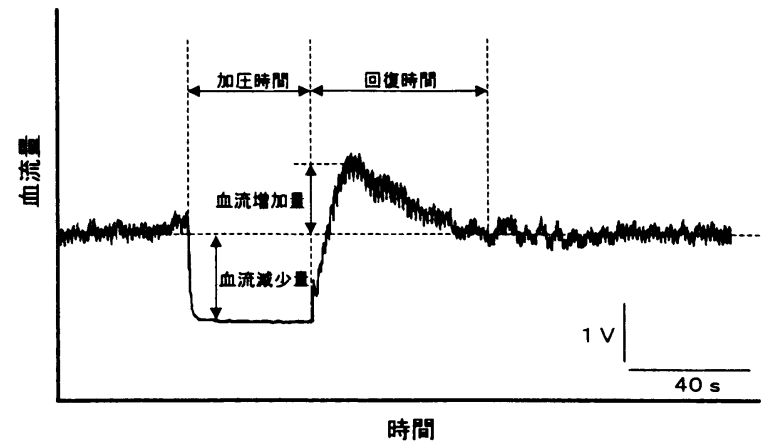

図 3 血流変化の典型的な原波形と分析項目

Fig. 3 A typical blood flow and analyzed items

時間を回復時間として求めた。さらに, 安静時ベースラ インと比較した加圧時の血流減少量と加圧後の血流増加 量を, 装置からの出力電圧として求めた。 なお, 加圧終 了後に血流量が加圧前のレベルに戻らない場合は，30秒 以上変動が認められない区間の血流レベルをベースライ ンとした。

\section{III. 結 果}

\section{1．測定部位におけるロ蓋粘膜厚径の測定}

各被験者の部位別の口蓋粘膜厚径を図 4 に示した。従 来の報告”と同様に，A点および $\mathrm{B}$ 点においては同一被 験者内でほほ同じ值を示したが, $\mathrm{C}$ 点では $\mathrm{A}$ 点, $\mathrm{B}$ 点の 1/2から1/3の值となり, クラスカルワーリス法により危 険率 $5 \%$ 以下で各測定部位の間で有意差が認められた (ダン法により有意差の見られた部位間を図中のアスタ リスクで示した)。

2. 血流量の測定

1 ）加圧部位の相違による血流量の変化

各被験者における加圧部位別の回復時間を図 5 に示し た、 $\mathrm{A}$ 点およびB点においては, 加圧終了後の血流量は 加圧前に比べ一時的に増加し，いわゆる反応性充血を示 した後に元のレベルに戻るケースが大部分を占めた。一 方，C点においては，反応性充血を示さずにそのまま加 圧前のレベルに戻るケースが 5 名中 2 名に見られ，これ らのケースでは回復時間を測定することができなかっ た. 他の 3 名では, 反応性充血は見られたもののその変 化が明確ではなく，その結果回復時間が延長する傾向が 見られた。

以上のことから $\mathrm{A}$ 点および $\mathrm{B}$ 点では明確な反応性充血

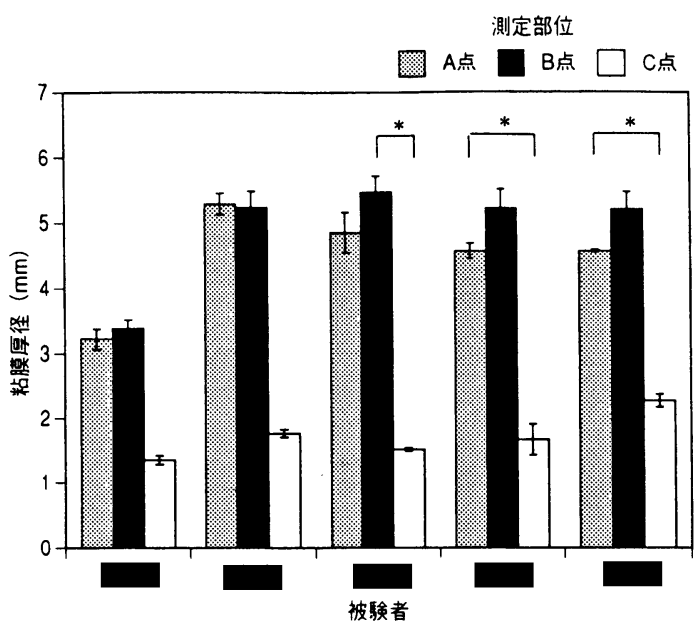

図 4 血流測定部位における口蓋粘膜厚径

Fig. 4 The thickness of the palatal mucosa in the measuring sites

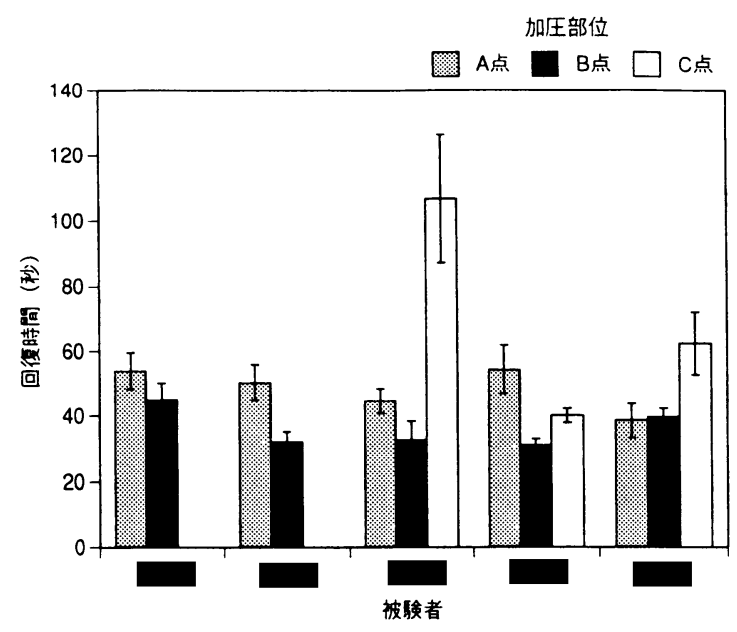

図 5 各加圧部位における回復時間

Fig. 5 The recovery period in each measuring site

が見られ，血流変化の動態を観察するのに適する部位で あると考えられた．また先に示したように，A点および B点ではほほ同様な粘膜厚径を有していたので，以下の 実験は $\mathrm{A}$ 点のみで行うことにした。

2 ) 加圧時間の相違による血流量の変化

各被験者において, 加圧時間を変化させたときの回復 時間の平均を図 6 に示した。いずれの被験者においても， 加圧時間10秒から30秒までの間では加圧時間の増加とと もに回復時間は延長する傾向がみられ，分散分析により 3 名の被験者において, 危険率 $5 \%$ 以下で加圧時間の違 いにより有意差が認められた。 
加压時间

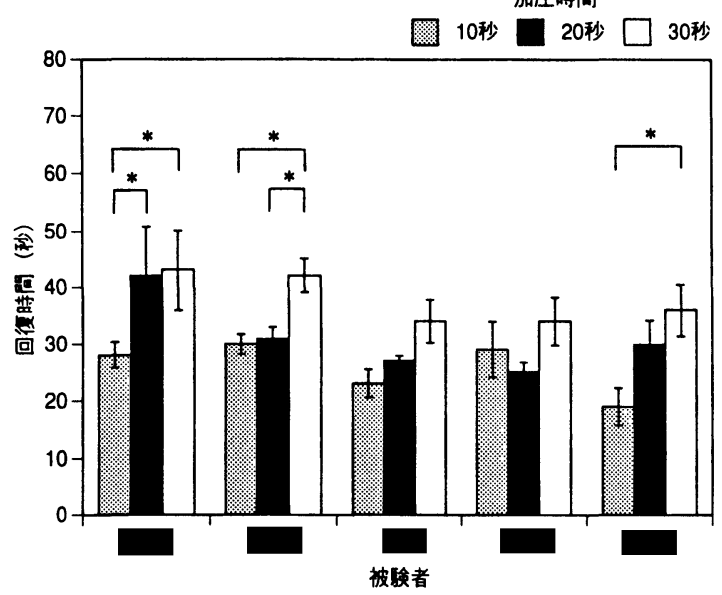

図 6 加圧時間と回復時間の関係

Fig. 6 The relation between the loading interval and the recovery period

加圧時間

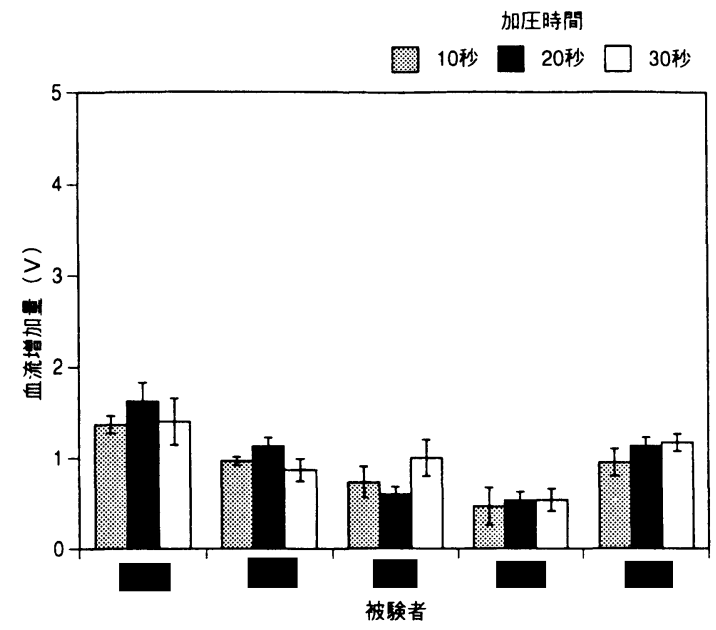

図 7 加圧時間と加圧後血流増加量の関係

Fig. 7 The relation between the loading interval and the increase in blood flow after the load removal

図 7 には，加圧時間を変化させたときの加圧後血流増 加量の平均を示した。加圧後血流増加量は, 同一被験者 内においては加圧時間に関係なくほほ一定の值を示し， 加圧時間による有意差は認められなかった。

次に, 加圧時間を変化させたときの加圧時血流減少量 の平均を図 8 に示した. 加圧時血流隇少量は加圧後血流 増加量と同様, 同一被験者内においては加圧時間に関係 なくほほ一定の值を示し, 加圧時間の違いによる有意差 は認められなかった。

3 ）荷重量の相違による血流量の変化

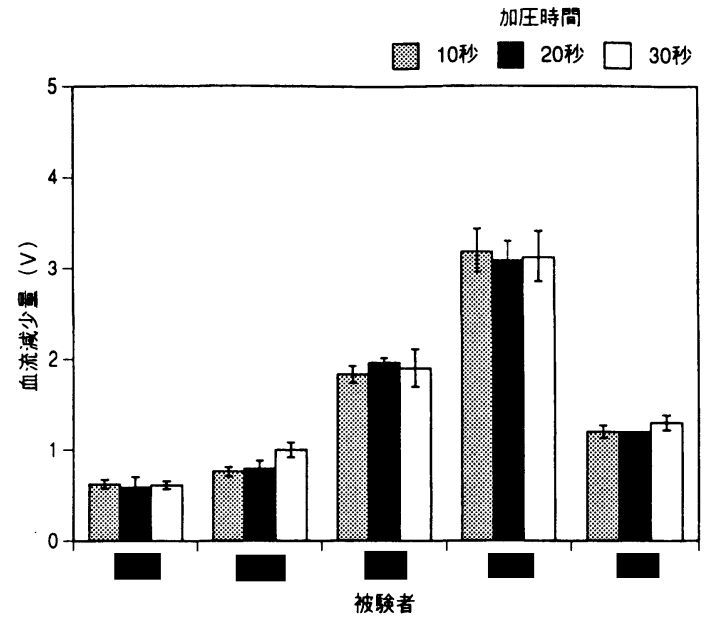

図 8 加圧時間と加圧時血流隇少量の関係

Fig. 8 The relation between the loading interval and the reduction in blood flow during the load

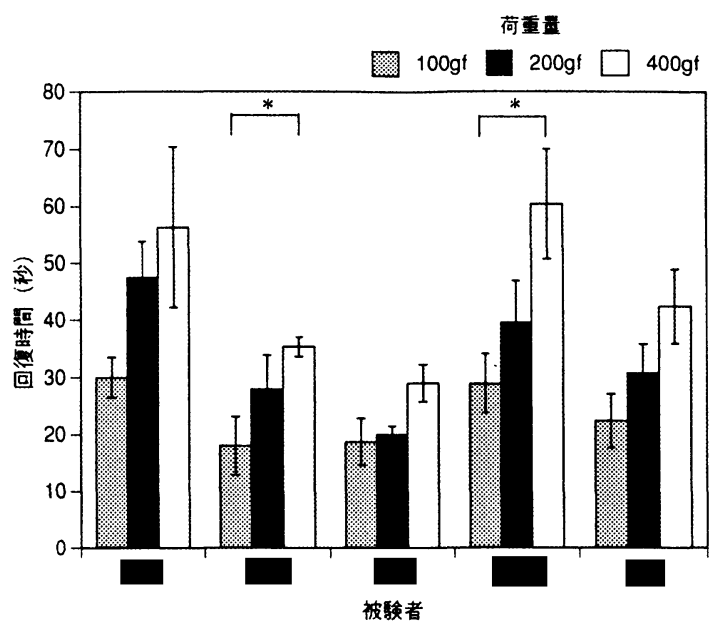

図 9 荷重量と回復時間の関係

Fig. 9 The relation between the loading intensity and the recovery period

各被験者において, 荷重量を変化させたときの回復時 間の平均を図 9 に示した。いずれの被験者においても， 荷重量の増大に伴い回復時間の延長がみられ, 分散分析 により 2 名の被験者において危険率 $5 \%$ 以下で荷重量に より有意差が認められた。

各被験者における荷重量別の加圧後血流増加量の平均 を図10に示した。同一被験者内においては, 荷重量を増 加したときの加圧後血流増加量には，一定の傾向は認め られなかった。

各被験者における荷重量別の加圧時血流減少量の平均 


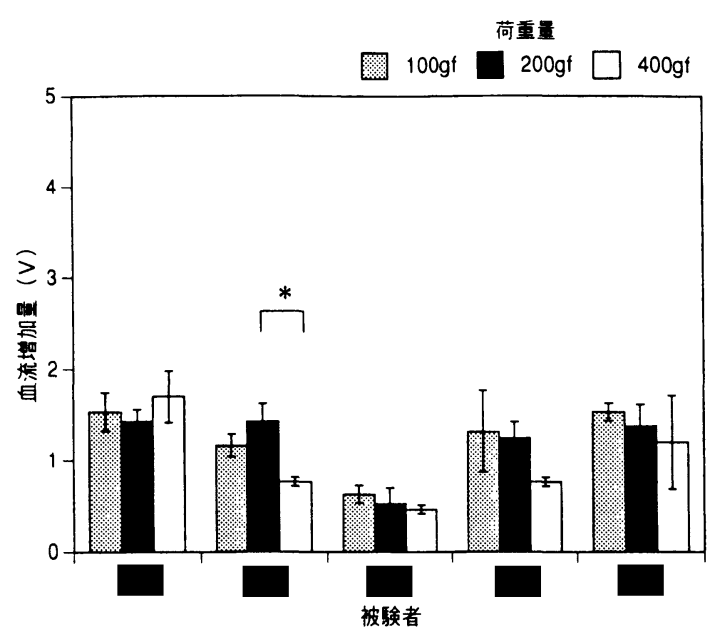

図10荷重量と加圧後血流増加量の関係

Fig. 10 The relation between the loading intensity and the increase in blood flow after the load removal

を図11に示した。荷重量増加に伴い加圧時血流減少量は 増大する傾向が見られ，4名の被験者において危険率 $5 \%$ 以下で荷重量により有意差が認められた。

\section{IV. 考 察}

\section{1. 測定装置および方法について}

口腔粘膜の血流測定には, インピーダンスプレチスモ

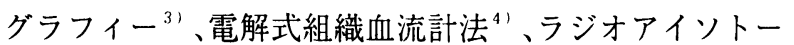

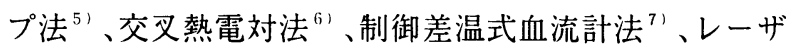
ードップラー血流計法 ${ }^{8-15)}$ などが知られいる. 近年開発 されたレーザードップラー血流計は, 生体に対する侵襲 性, 操作の簡便性, 測定の再現性, 連続性などの種々の 問題点を改良し，幅広く使用されるようになった。その 原理は, プローブから射出されたレーザー光が, 組織表 層の毛細血管内を流れる赤血球に衝突し反射・散乱され ると, ドップラーシフトにより反射波の周波数が変化し, この入射波と反射波の周波数のずれが, 血流速度（血流 量）に比例することを応用している.

本実験で用いたレーザードップラー血流計は，プロー ブやファイバーを確実に固定しなければ測定值の変動が 大きいことが指摘されている，ヒト上顎前歯部唇側歯肉 の血流を測定した小野 ${ }^{11}$ や山倉ら ${ }^{91}$ は, 歯に固定源を求 めたステントを作製してプローブの固定を行っている. 制御差温式組織血流計によって口蓋粘膜の加圧時の血流 を測定した角谷ら”は，センサーをロ蓋粘膜に貼付した うえで，センサー周囲の粘膜に加圧するための加圧用カ

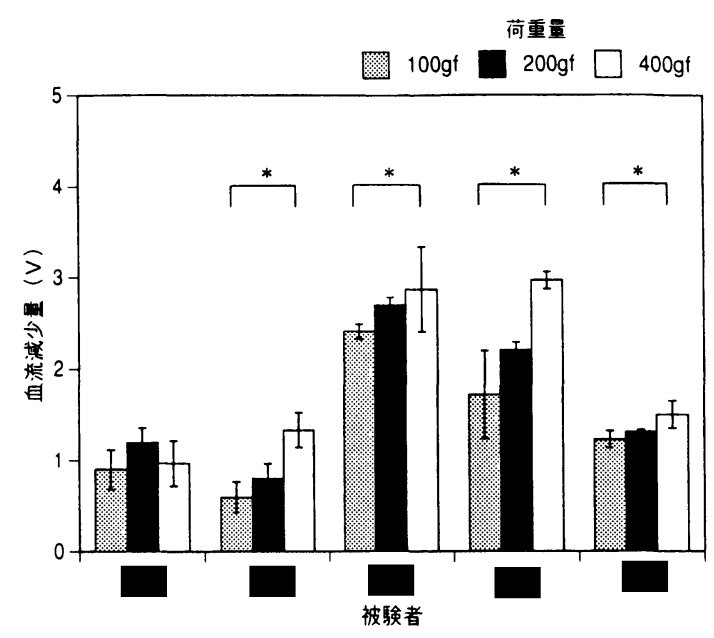

図11荷重量と加圧時血流減少量の関係

Fig. 11 The relation between the loading intensity and the reduction in blood flow during the load

バーフレームと，これを保持して歯に固定するためのメ タルキャップを用いている。一方, Hokeら ${ }^{141}$ は, レー ザードップラー血流計による付着歯肉の血流測定につい て，プローブを手指で操作した場合とステントで固定し た場合とで比較したところ, 両者で測定の信頼性に差が なかったと報告している。

本実験では，上顎歯列に固定源を求めたレジン製ステ ントを作製し, 各測定部位にプローブ径よりもわずかに 大きい径の穴を開けるとともに，プローブから数 $\mathrm{cm}$ 離 れた部位でファイバーをステントに固定するための連結 装置を設けた。これらにより, 非加圧時にはプローブは 粘膜に無圧の状態で接触し, プローブ加圧時には軸方向 にわずかに可動するような機構が可能となった。プロー ブ加圧前後のプローブの動摇により血流值が影響を受け ると思われるが, この影響は主として安静時血流のベー スラインの変動として現われることが観察された。この ように加圧の前後で安静時血流レベルが一致しない場合 には, 加圧後の安静時血流レベルを参照することにより 回復時間や血流増加量を分析した. 同一条件下における これらの值の標準偏差は比較的小さく再現性も良好であ ったことから, 加圧の前後で安静時血流レベルが一致し ない場合でも, 加圧後の安静時血流レベルを参照するこ とにより，加圧による血流の動態を観察することが可能 であると考えられる。

\section{2. 測定部位について}

口蓋粘膜厚径の部位による差異について, 寺倉 ${ }^{\prime \prime}$ は, 口蓋正中部において最も小さく，口蓋後側方部において 
最も大きいと報告している。この結果は, 宮下 ${ }^{21}$ の報告 による口蓋粘膜の被圧変位量の大きさと一致している. 今回の実験では, 口蓋粘膜が比較的厚く, 大口蓋孔から 出る大口蓋動脈の枝が前走している部分 $(\mathrm{A}, \mathrm{B}$ 点）と, 粘膜が菲薄で，大口蓋動脈の枝がさらに分枝している部 分（C点）について血流測定を行った。その結果， $\mathrm{A}$ 点 およびB点においては，ほとんどの条件下で加圧終了後 に反応性充血を示したが，C点においては，反応性充血 を示さずにそのまま加圧前のレベルに戻るケースや，反 応性充血は見られたもののその変化が明確ではない場合 が多く, 部位によって血流動態に明らかな違いが観察さ れた。

\section{3. 測定条件について}

測定条件の一つである加圧時間については，術者が加 圧装置からの出力を観察しながら，一定の荷重量で粘膜 を加圧するのに必要な時間として10秒を最小の条件と し，さらに，20，30秒と加圧時間を延長したときの血流 変化を検討した，なお，加圧部位および荷重量の相違に よる血流変化の実験に際しては, 加圧時間をさらに延長 して40秒とし，加圧時間の誤差による影響を少なくする よう考慮した。

一方の荷重量については, 被験者の口蓋粘膜を加圧し た際に，荷重量が400gfを超えると一部の被験者で疼痛 を感じることが認められたので，本実験では400gfを最 大の荷重量とし，以下その1/2ずつの200gf，100gfを測 定条件に加えて, 荷重量が血流量に及ほす影響を検討す

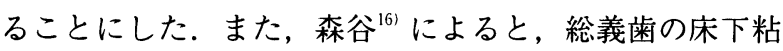
膜上に加わる咬合圧は，上顎では中心咬合位の場合の口 蓋部において最大 $\left(2.2 \sim 5.7 \mathrm{~g} / \mathrm{mnn}^{2}\right)$ とされているが, 本 実験で負荷した荷重量はいずれもこれより大きく，荷重 量 $400 \mathrm{gf}$ (圧力 $\left.32.85 \mathrm{~g} / \mathrm{mm}^{2}\right)$ ではほほ阻血されて, 臨床的 には潰瘍や変形を生じると考えられる。

\section{4. 血流波形について}

血流量に変化を及ほす影響として外来刺激"1 や炎症な どによる毛細血管の分布状態の変化 ${ }^{17}{ }^{181}$ の他に，血流の 自然動摇 ${ }^{191}$ が知られている。自然動摇には，心拍の影響 によって起こる拍動性動摇, 呼吸によって起こる呼吸性 動摇，そして微小循環系血管網において生起する血管運 動性の動摇がある. 今回，図 3 に示した原波形に見られ る小さな波は約 1 秒間隔で現れ，その周期から拍動性動 摇によるものと思われる.

角谷ら は加圧後に見られる反応性の充血をリバウン ドと呼び，その発現率は圧力の大きさとの間に正の相関 関係があると報告している。また，Baabら ${ }^{81}$ は上顎前 歯部唇側の歯間乳頭, 遊離歯肉, 付着歯肉, 歯槽粘膜部
において, 直径 $2.5 \mathrm{~mm}$ のプローブを用いて $1.5 \mathrm{~N}$ のカで 60 秒加圧した場合，どの部位でも反応性の充血が見られ たと報告している.小野"11 は上顎犬歯部唇側歯肉に $400 \mathrm{~g} / \mathrm{cm}^{2}$ 程度までの繰り返し荷重を加えた場合に隣接する歯肉部 の血流が増加し, 痛みを感じる程度の強い刺激を加えた 際にはきわめて長い時間経過をもつ大きな血流増加反応 が観察されたと報告している。本研究で, 口蓋後側方部 に加えた荷重は圧力值で表すと，796，1592，3185 g/cm となり，比較的大きな荷重量で加圧したことが，ほとん どの場合で反応性充血が認められた理由であると考えら れる，一方，口蓋正中部で反応性充血が必ずしも見られ なかったことについては, 粘膜厚径が口蓋後側方部に比 較して菲薄であることや，血管の分布が少ないことなど の組織学的な違いが関連しているものと推察される.

反応性充血は, 一過性の血行遮断あるいは血管閉塞の 負荷解除後に起こる受動的な充血であり, 種々の蔵器で 観察されている，その原因として，加圧により阻血が起 こり管内圧変化を生じ, 血流の再開とともに多くの血液 が流入すること, 阻血によって血管拡張性の代謝物質が 産生され，血流再開と同時に末梢血管の拡張を引き起こ すこと、交感性血管収縮神経が機械刺激により抑制され ることなど種々考えられている11, 19-211. しかし, 反応性 充血の発現率と加圧量の大きさとの間に正の相関がある とする過去の報告”や，今回の実験結果のように，部位 によっては反応性充血が現れないことを考慮すると，反 応性充血の発現には, 代謝産物や交感神経の影響という よりも,むしろ加圧により管内圧変化を生じるような組 織構造の特性が主として関与していることが示唆され る.

\section{5. 加圧時間の相違による血流量の变化について}

加圧時間を増加した場合, 回復時間は延長する傾向が みられた。これに対して，加圧時血流減少量ならびに加 圧後血流増加量は加圧時間に関係なく一定となる傾向を 示した．松浦 22 は，カニクイザルの口蓋粘膜を加圧した ときの粘膜の変位を測定し, 加圧除去後粘膜の变位は急 速に回復しはじめるが，その後回復の速度が徐々に減少 することを報告しているように，顎粘膜が粘弾性挙動を 示すことは古くから知られている淿. 本実験で観察され た, 加圧後の血流変化も粘膜の粘弾性的変化とよく類似 している，今回の実験結果を管内圧变化と粘膜の粘弾性 に関連づけると，次のように推論することができる．す なわち，加圧除去により周囲との大きな圧力差によって， 側副血流が阻血していた部位に一過性に流入し血流が増 加する. その後，血流はわずかな圧力差によって周囲へ 流出しょうとするが, 圧縮された血管径の回復が緩徐と 


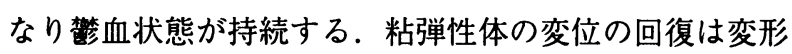
時間に依存するので，今回の実駼結果にみられるように， 加圧時間が増加するほど回復時間が延長することが考え られる。加圧時血流減少量は, 一定荷重下でほほ阻血の 状態にあれば当然，加圧時間に関係なく一定となる．加 圧後の血流増加量は, 粘膜の圧縮が急速に回復する弾性 要素の強い時点での現象であり, このときの血流増加量 は加圧時間の影響を受けにくいか, あるいは, 血流増加 量が加圧時間に関係なくすでに飽和量に達していること が考えられる.

\section{6. 荷重量の相違による血流量の変化について}

荷重量を増加した場合には，加圧時間を増加した場合 と同様に回復時間が延長する傾向がみられ，また，加圧 時血流減少量も荷重量の増大に伴って増大する傾向にあ った，粘膜の圧縮変位量は荷重量と相関しており，荷重 量が大きいほど血管径も圧縮されて血流が阻害される し, 回復に要する時間も延長することが推察される。一 方, 加圧後血流増加量については, 荷重量の変化によっ て一定の傾向は認められなかった。これに関しては，実 験の精度の向上を含めてさらに検討が必要であると思わ れる。

\section{V. 結 論}

口蓋粘膜への荷重負荷が血流量に及ぼす影響を解明す るため, レーザードップラー血流計を用いて種々の条件 下での血流測定を行い検討したところ，以下の結果なら びに結論を得た。

1. 加圧部位の相違による血流量変化については，口蓋 後側方部の左右両側では加圧終了直後に反応性の充血 がほとんどの条件下でみられたが，口蓋正中部ではこ れとは異なった動態を呈した。

2. 加圧時間の相違による血流量変化については，加圧 時間が増加した場合，回復時間は延長する傾向がみら れた。これに対して，加圧時血流減少量ならびに加圧 後血流増加量は加圧時間に関係なく，ほほ一定となる 傾向を示した。

3. 荷重量の相違によって, 加圧後血流増加量は特徵的 な傾向を示さなかったが, 回復時間は荷重量が増加し た場合に延長する傾向がみられた。また，加圧時血流 減少量も荷重量増加に伴って増大する傾向を示した。 以上の結果より，口蓋粘膜へ荷重を負荷した場合の血 流変化にはある一定の規則性が認められた。このことか ら, 荷重負荷による血流動態の変化は, 義歯床下粘膜の 特性を評価する指標として有用であることが示唆された。

\section{文献}

1) 寺倉健：顎粘膜厚径の非侵襲的測定法の検討, 補経 誌, $30 ： 1402-1411,1986$.

2 ) 宮下恒太：顎粘膜の局所被圧変位度と咬合力による 義歯床の沈下度とに関する研究, 歯科学報, 70 : 38-68, 1970.

3 ）鳥居建吾：Impedance Plethysmography による上顎口 蓋粘膜血流量に関する研究，歯学，61: 788-799, 1973.

4 ）江口芳美, 榎本友彦, 立浪徹ほか：電解式組織血流 計による床下支持粘膜血流量測定の検討, 歯学, 73: 1582-1585, 1986.

5 ) Atasever, N.E., Ercan, M.T., Naldöken, S. et al.: Effect of wearing complete dentures on human palatal mucosal blood flow measured by ${ }^{133} \mathrm{Xe}$ clearance, Archs Oral Biol, 36: 627-630, 1991.

6 ）松川英彦，伊藤春生，高橋和人：交叉熱電対法の口 蓋粘膜循環動態への応用, 神奈川蒾学, 7: 112-119, 1972.

7 ) 角谷真一, 松永匡司, 佐藤隆志ほか：制御差温式組 織血流計を用いた口蓋粘膜の加圧時血流動態に関す る研究, 補緅誌, 37: 488-493, 1993.

8 ) Baab,D.A., Öberg, P.Å. and Holloway,G.A.: Gingival blood flow measured with a laser doppler flowmeter, J Periodont Res, 21: 73-85, 1986.

9 ) 山倉久史, 岡田菜穂子, 戸塚明美ほか：レーザード ップラー血流計を用いた歯肉毛細血管血流量の基礎 的研究，日歯周誌，28: 646-653, 1986.

10) Baab, D.A., Öberg, Å. and Lundström, Å.: Gingival blood flow and temperature changes in young humans with a history of periodontitis, Archs Oral Biol, 35: 95-101, 1990.

11）小野和宏：ヒト歯および歯肉への機械的刺激による 歯肉の反射性血流增加について，口科誌，39: 389-404, 1990.

12）瀧川博嗣：レーザードップラー血流計による歯肉, 口蓋粘膜および皮䖉面の血流測定に関する補緅学的 検討, 補緅誌, 36: 41-52, 1992.

13）加藤光雄，幸阪保雄，後藤忠正ほか：義歯床下粘膜 の血流変化 一レーザー表層血流計の応用一, 補緅 誌, 36: 126-135, 1992

14) Hoke, J.A., Burkes, E.J., White, J.T. et al.: Blood-flow mapping of oral tissues by laser Doppler flowmetry, Int J Oral Maxillofac Surg, 23: 312-315, 1994. 
15）水野二郎：部分床義歯装着前後の支台歯付着歯肉お よび残遺歯槽堤の血流動態, 補綴誌, 39: 670-682, 1995.

16）森谷良彦：総義歯の咬合力に関する研究補遺, 補緅 誌, 11: 1-23, 1967.

17) Kaplan, M.L., Jeffcoat, M.K. and Goldhaber, P.: Blood flow in gingiva and alveolar bone in beagles with periodontal disease, J Periodont Res, 17: 384-389, 1982.

18）河村達也：有床義歯が床下粘膜に及ほす影響 特に 血管構築について, 補緅誌, 33: 710-723, 1989.

19）浅野牧茂：微小循環, 沖野遥, 菅原基晃, 松尾裕英 編：心臟血管系の力学と基礎計測, 337-372, 講談
社, 東京, 1980 .

20）松川英彦：口腔内微小循環の生理および薬理，神奈 川歯学, 11: 170-193, 1976.

21) Schlenker, J.D. and Reus, W.F.: Blood flow after warm ischemia in island flaps: Latissimus dorsi myocutaneous and epigastric flaps in the dog, Ann Plast Surg, 10: 55-64, 1983.

22）松浦基一：口蓋部軟組織の加圧時の変化ならびにそ の組織学的研究, 口病誌, 46: 323-362, 1979.

23）佐久間孔毅：無歯顎印象採得のレオロジーによる検 討, 歯材器, 12: 79-124, 1965. 